\title{
PERFORMANCE OF ELECTRICAL DISCHARGE MACHINING (EDM) WITH NICKEL ADDED DIELECTRIC FLUID
}

\author{
Ahsan Ali Khan ${ }^{1}$, Muataz Hazza Faizi Al Hazza ${ }^{*}$, A K M MohiUddin ${ }^{2}$, \\ Nurfatihah Abdul FatTah ${ }^{1}$ AND Mohd Radzi Che DAUd ${ }^{1}$ \\ ${ }^{1}$ Department of Manufacturing and Materials Engineering, \\ ${ }^{2}$ Department of Mechanical Engineering, \\ Faculty of Engineering, International Islamic University Malaysia, \\ Jalan Gombak, 53100 Kuala Lumpur, Malaysia. \\ *Corresponding author: muataz@iium.edu.my
}

(Received: 20th Oct 2016; Accepted: $15^{\text {th }}$ Nov 2017; Published on-line: $1^{\text {st }}$ June 2018)

https://doi.org/10.31436/iiumej.v19i1.759

\begin{abstract}
In this study, the effect of nickel powder mixed dielectric fluid on Electrical Discharge Machining (EDM) performance of mild steel has been carried out. Peak current, tool/electrode diameter and concentration of powder are the process parameters. The process performance is measured in terms of material removal rate (MRR), tool wear rate (TWR), and surface roughness (SR). The experiment has been designed using a Full Factorial in Design of Experiment (DOE) software. The research outcome is to identify the important process parameters that maximize MRR and minimize TWR and SR. The experiment has been carried out using 2 levels of current $(3.5 \mathrm{~A}$ and $6.5 \mathrm{~A})$, tool diameters $(14 \mathrm{~mm}$ and $20 \mathrm{~mm})$ and Nickel powder concentrations $(0 \mathrm{~g} / 1$ and $6 \mathrm{~g} / 1)$. The weight of the mild steel work piece and copper electrode are measured before and after each run. Based on the results, current is the most significant parameter affecting MRR, TWR, and SR. It was also found that with added nickel powder in the dielectric fluid, the tool life is longer and surface roughness of the work piece is improved. Furthermore, it was shown that both MRR and TWR increased with the increase in tool diameter. However, SR was improved as tool diameter increased but its effect was not very significant.
\end{abstract}

ABSTRAK: Dalam kajian ini, mutu keberhasilan campuran serbuk nikel cecair dielektrik pada Sisa Mesin Elektrik (EDM) ke atas besi ringan telah dijalankan. Arus tertinggi, alat/diameter elektrod dan ketumpatan serbuk adalah parameter kawalan. Pencapaian proses diukur dari segi kadar penyingkiran bahan (MRR), kadar penggunaan alat (TWR) dan kekasaran permukaan (SR). Eksperimen ini direka bentuk dengan menggunakan perisian Faktorial Penuh dalam Rekaan Eksperimen (DOE). Hasil kajian ini adalah untuk mengidentifikasi kepentingan parameter kawalan yang mengoptimumkan MRR, meminimumkan TWR dan SR. Eksperimen ini dijalankan pada 2 peringkat arus elektrik (3.5 A dan $6.5 \mathrm{~A})$, diameter alat $(14 \mathrm{~mm}$ dan $20 \mathrm{~mm})$ dan ketumpatan serbuk nikel $(0 \mathrm{~g} / 1$ and $6 \mathrm{~g} / \mathrm{l})$. Berat bahan uji seperti besi ringan dan elektrod tembaga diukur pada sebelum dan selepas setiap ujian. Berdasarkan keputusan, arus elektrik adalah faktor paling ketara yang mempengaruhi MRR, TWR, dan kekasaran permukaan. Turut didapati pada setiap pertambahan serbuk Nikel ke dalam cecair dielektrik, jangka hayat alat turut bertambah dan kekasaran permukaan pada bahan uji turut bertambah baik. Selain itu, kedua-dua MRR dan TWR bertambah dengan setiap pertambahan diameter alat. Sebaliknya, kekasaran permukaan bertambah baik dengan pertambahan diameter alat tetapi kesannya tidak ketara.

KEYWORDS: EDM; dielectric fluid 


\section{INTRODUCTION}

Using a non-traditional method such as electro-discharge machining (EDM) can solve the problems in the machining of high complexity shapes with higher accuracy and better surface finish. Sandeep [1] described EDM as one of the non-traditional machining processes where an electrical spark is generated by electrical energy and the thermal energy of the spark causes material removal. In EDM, electric discharges occurring between two electrodes immersed in a dielectric fluid, cause metal to be removed from a work piece. Webzell [2] mentioned that the history of EDM techniques started in 1770, when English scientist Joseph Priestly noticed that electrical discharges, or sparks, have erosive effect. However, soviet scientists exploited the destructive properties of electrical discharges for constructive use and developed a controlled method of metal machining to machine metals by vaporizing material from the surface of the metal. Furthermore, in the 1950s, Lazarenko EDM systems that used a resistance-capacitance type of power supply were widely used in EDM machines, and later acted as models to enhance EDM [3].

Zhao et al. [4] mentioned that despite EDM's ability to produce high complexity shapes and to machine materials regardless of that material's hardness, further applications are limited due to low machining efficiency and poor surface finish. Thus, to improve the machining efficiency and surface finish, powder mixed electrical discharge machining $(\mathrm{PMEDM})$ ) is a new process of material removal where powder is mixed into the dielectric fluid [4,5]. Similarly, Sharma et al. [6] indicated that powder- mixed dielectric electric discharge machining (PMD-EDM) is a new approach to improve the process' capabilities. The gap distance and discharging rate also increased by adding powder into the dielectric fluid because the additive particles of powder mixed in the dielectric play significant roles in the discharge process. The conductive powder particles are energized by the high electric field and these conductive particles develop chains at different spots under the sparking area, thereby reducing the gap between electrode and work piece material. Thus, because of this reduction effect, the gap voltage and insulating strength of the dielectric decreases and causes easy short circuiting. Therefore, there is a discharge in the gap between the work piece and the electrode. Due to electric density decreases; the suspended particles in the dielectric simultaneously broaden the plasma channel. Hence, uniform distribution of the sparking takes place.

Abbas et al. [7] indicated that the EDM process becomes more stable and enhances the material removal rate (MRR), machining efficiency, and surface quality when fine abrasive powder is mixed into the dielectric fluid. The dielectric performance is influenced by characteristics of the powder such as the type, size, and concentration [8].

Jeswani [9] investigated the effect of the addition of $4 \mathrm{~g}$ of graphite powder to kerosene and stated that the material removal rate (MRR) was enhanced by $60 \%$ and electrode wear ratio was decreased by $15 \%$. Prihandana et al. [10] presented a new approach using ultrasonic vibration during the micro-EDM processes that consisted of suspending micro $\mathrm{MoS}_{2}$ powder in dielectric fluid. According to her, MRR was significantly increased and surface quality also improved using this new method. Kansal et al. [11] enhanced the process parameters of powder mixed electrical discharge machining (PMEDM) on tool steel using response surface methodology. According to them, using silicon powder mixed in the dielectric fluid of EDM, MRR improved at maximum concentration rate of silicon powder.

Yan et al. [12] reported that using urea solution in distilled water, the MRR obtained had no significant difference compared to conventional water dielectrics and it was more suitable for the post EDM process, for example as coating for the machined surface to induce 
better wear resistance. MRR increased in the dielectric when peak current was increased and MRR decreased with an increase in pulse duration.

Ojha et al. [13] studied the effect of a nickel micro powder mixed dielectric on EDM performance measures on EN-19 steel and proposed that the tendency of MRR to increase in any value of current and others factor is higher. The maximum MRR is obtained at high current and MRR increases with the increase in tool diameter owing to the increase in current. However, the MRR tends to decrease after a certain level of range of $12 \mathrm{~mm}$ due to inefficient flushing. Also, with duty cycle and powder concentration, MRR tends to increase but the effect was not significant

This study sought to investigate the effect of nickel powder mixed dielectric fluid on machining characteristics of mild steel. Peak current, tool/electrode diameter, and concentration of powder were chosen as process parameters while material removal rate (MRR), tool wear rate (TWR) and surface roughness (SR) were chosen as process performance indicators.

\section{EXPERIMENTAL PROCEDURE}

A pure copper electrode with a diameter of $15 \mathrm{~mm}$ and $20 \mathrm{~mm}$ was applied as a tool electrode. The type of work piece was mild steel. Table 1 shows chemical composition of AISI 1018 mild steel.

Table 1: Chemical composition of AISI 1018 mild steel

\begin{tabular}{cccccc}
\hline Element & $\mathbf{C}$ & $\mathbf{F e}$ & $\mathbf{M n}$ & $\mathbf{P}$ & $\mathbf{S}$ \\
\hline Content & $0.14-.20 \%$ & $98,81-99.26 \%$ & $0.60-0.90 \%$ & $<0.040 \%$ & $<0.050 \%$ \\
\hline
\end{tabular}

Nickel is the type of powder that was used for this experiment. Kerosene was used as the dielectric fluid. To investigate the effect of the process parameters on PMEDM performance, the Design Expert version 6.0.8 software was used. A full factorial experiment was conducted for three independent factors: current, powder concentration, and tool diameter, each with two levels to investigate their effect on material removal rate, tool wear rate, and surface roughness. The total number of experimental runs was 8 , as shown in Table 2.

Table 2: experiment design

\begin{tabular}{cccc}
\hline Pattern & $\begin{array}{c}\text { Current } \\
(\mathbf{A})\end{array}$ & $\begin{array}{c}\text { Powder concentration } \\
\text { (g/l) }\end{array}$ & $\begin{array}{c}\text { Tool diameter } \\
(\mathbf{m m})\end{array}$ \\
\hline--- & 3.5 & 0 & 14 \\
+-- & 6.5 & 0 & 14 \\
++- & 6.5 & 6 & 14 \\
-++ & 3.5 & 6 & 20 \\
+++ & 6.5 & 6 & 20 \\
+-+ & 6.5 & 0 & 20 \\
--+ & 3.5 & 0 & 20 \\
-+- & 3.5 & 6 & 14 \\
Note: $(+)$ is the high level; (-) is the low level for each independent factor.
\end{tabular}


The experiments were conducted using the EDM die-sinking machine, MITSUBISHI EX22 Model C11E FP60E. The machine was located at the tool and dies lab, ground floor of engineering building E0, Faculty of Engineering, International Islamic University Malaysia.

\section{RESULTS}

Material removal rate, tool wear rate, and surface roughness were measured and are displayed in Table 3.

Table 3: MRR, TWR, and Ra

\begin{tabular}{ccccccc}
\hline Pattern & $\begin{array}{c}\text { Current } \\
(\mathbf{A})\end{array}$ & $\begin{array}{c}\text { Powder } \\
\text { concentration } \\
(\mathbf{g} / \mathbf{l})\end{array}$ & $\begin{array}{c}\text { Tool } \\
\text { diameter } \\
(\mathbf{m m})\end{array}$ & $\begin{array}{c}\text { MRR } \\
(\mathrm{g} / \mathbf{m i n})\end{array}$ & $\begin{array}{c}\text { TWR } \\
(\mathbf{m g} / \mathbf{m i n})\end{array}$ & $\begin{array}{c}\text { Ra } \\
(\boldsymbol{\mu m})\end{array}$ \\
\hline--- & 3.5 & 0 & 14 & 0.0137 & 0.814 & 3.29 \\
+-- & 6.5 & 0 & 14 & 0.724 & 3.517 & 32.05 \\
++- & 6.5 & 6 & 14 & 0.3112 & 1.669 & 28.06 \\
-++ & 3.5 & 6 & 20 & 0.0133 & 0.216 & 2.217 \\
+++ & 6.5 & 6 & 20 & 0.4082 & 2.055 & 21.463 \\
+-+ & 6.5 & 0 & 20 & 0.4768 & 2.239 & 32.203 \\
--+ & 3.5 & 0 & 20 & 0.014 & 0.317 & 2.97 \\
-+- & 3.5 & 6 & 14 & 0.0144 & 0.053 & 2.993 \\
\hline
\end{tabular}

\section{STATISTICAL ANALYSIS}

Regression analysis and analysis of variance (ANOVA) are the most frequently applied statistical analyses in engineering research. The analysis of variance for the quadratic models was conducted. The results of the suggested models for a $5 \%$ level of significance were implemented. Table 4, 5, and 6 show the ANOVA tables for the MRR, TWR, and Ra respectively.

Table 4: ANOVA table for MRR

\begin{tabular}{ccccc}
\hline Source & DF & $\begin{array}{c}\text { Sum of } \\
\text { Squares }\end{array}$ & $\begin{array}{c}\text { Mean } \\
\text { Square }\end{array}$ & F Ratio \\
\hline Model & 4 & 0.46527562 & 0.116319 & 11.5595 \\
Error & 3 & 0.03018787 & 0.010063 & Prob $>$ F \\
C. Total & 7 & 0.49546350 & & $\underline{\mathbf{0 . 0 3 6 2 *}}$ \\
\hline
\end{tabular}

Table 5: ANOVA table for TWR

\begin{tabular}{ccccc}
\hline Source & DF & $\begin{array}{c}\text { Sum of } \\
\text { Squares }\end{array}$ & $\begin{array}{c}\text { Mean } \\
\text { Square }\end{array}$ & F Ratio \\
\hline Model & 4 & 9.1224735 & 2.28062 & 14.2283 \\
Error & 3 & 0.4808624 & 0.16029 & Prob $>$ F \\
C. Total & 7 & 9.6033359 & & $0.0272^{*}$ \\
\hline
\end{tabular}


Table 6: ANOVA table for Ra

\begin{tabular}{ccccc}
\hline Source & DF & $\begin{array}{c}\text { Sum of } \\
\text { Squares }\end{array}$ & $\begin{array}{c}\text { Mean } \\
\text { Square }\end{array}$ & F Ratio \\
\hline Model & 4 & 1327.9161 & 331.979 & 76.6790 \\
Error & 3 & 12.9884 & 4.329 & Prob $>$ F \\
C. Total & 7 & 1340.9045 & & $0.0024^{*}$ \\
\hline
\end{tabular}

ANOVA tables show that all the three models had significant effect with $p$ values of 0.0362 , 0.0272 and 0.0024 for MRR, TWR, and Ra respectively, as shown in Tables 4, 5, and 6. For more detail, the sorted parameter estimates were created for the three responses as shown in Tables 7, 8, and 9 .

Tables 7: Sorted parameter estimates for MRR

\begin{tabular}{l|c|c|c|c|c}
\hline Term & Std Error & t Ratio & \multicolumn{2}{c|}{ t Ratio } & Prob>|t| \\
\hline current (A)(3.5,6.5) & 0.035466 & 6.28 & & $\mathbf{0 . 0 0 8 1 *}$ & \\
powder concentration(0,6) & 0.035466 & -1.99 & & & 0.1411 \\
current (A)*powder concentration & 0.035466 & -1.41 & & $\square$ & 0.2542 \\
powder concentration*tool diameter & 0.035466 & 0.92 & & & 0.4263 \\
$(\mathrm{~mm})$ & & & & & \\
\hline
\end{tabular}

Tables 8: Sorted parameter estimates for TWR

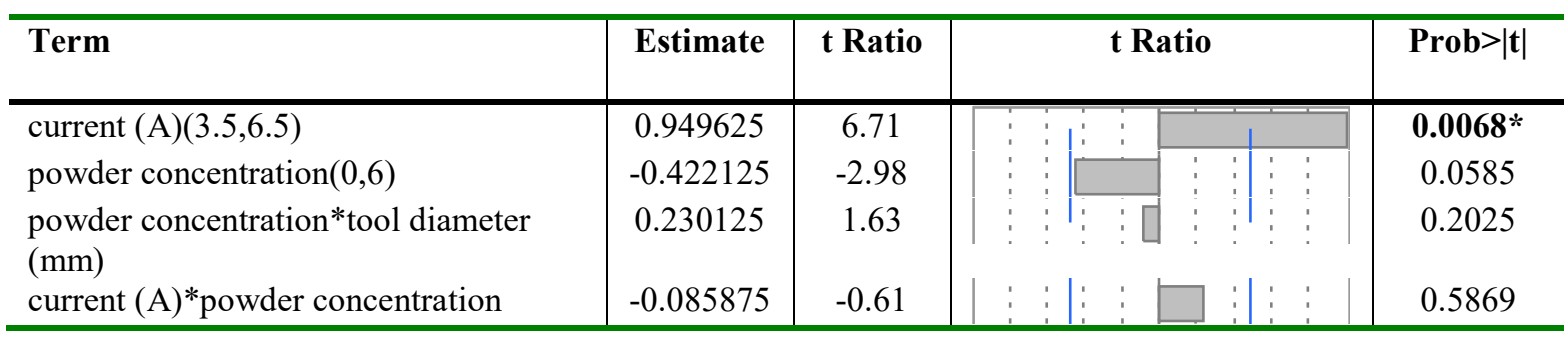

Tables 9: Sorted parameters estimate for $\mathrm{Ra}$

\begin{tabular}{|c|c|c|c|c|}
\hline Term & Estimate & t Ratio & t Ratio & Prob $>|\mathbf{t}|$ \\
\hline current $(\mathrm{A})(3.5,6.5)$ & 12.556375 & 17.07 & & 0.0004* \\
\hline powder concentration $(0,6)$ & -2.204375 & -3.00 & & 0.0578 \\
\hline current $(\mathrm{A}) *$ powder concentration & -1.478125 & -2.01 & - & 0.1381 \\
\hline $\begin{array}{l}\text { powder concentration*tool diameter } \\
(\mathrm{mm})\end{array}$ & -1.132625 & -1.54 & П & 0.2213 \\
\hline
\end{tabular}

Sorted parameters estimate figures show that the most effective factor on the dependent responses is the current value. The current affected positively on the MRR. In contrast, the influence of increasing the current value leads to negative effect on both the TWR and Ra. Finally the measures of fit were extracted from the software and concluded in Table 10. Both the results of the ANOVA table and the summary of fit proved that the models can be used for predicting the MRR, TWE, and Ra. One of the main outputs for the research was the three mathematical models: MRR model, TWR model and Ra model. 
Table 10: Summary of fit

\begin{tabular}{lccc}
\hline & MRR & TWR & Ra \\
\hline RSquare & 0.939071 & 0.949928 & 0.990314 \\
RSquare Adj & 0.857833 & 0.883164 & 0.977399 \\
Root Mean Square Error & 0.100313 & 0.400359 & 2.080737 \\
Mean of Response & 0.257238 & 1.420375 & 15.88763 \\
Observations (or Sum Wgts) & 8 & 8 & 8 \\
\hline
\end{tabular}

\section{MRR Model}

$$
\begin{aligned}
& 0.257+0.22 *\left(\frac{(\text { current }(\mathrm{A})-5)}{1.5}\right)-0.07 *\left(\frac{(\text { powder concentration }-3)}{3}\right)-0.008 *\left(\frac{(\text { tool diameter }(\mathrm{mm})-17)}{3}\right) \\
& +\left(\frac{(\text { current }(\mathrm{A})-5)}{1.5}\right) *\left(\left[\left(\frac{(\text { powder concentration }-3)}{3}\right) *-0.049\right)+\left(\frac{(\text { current }(\mathrm{A})-5)}{1.5}\right) *\left(\left[\frac{(\text { tool diameter }(\mathrm{mm})-17)}{3}\right) * 0.028\right)\right. \\
& +\left(\frac{(\text { powder concentration }-3)}{3}\right) *\left(\left[\frac{(\text { tool diameter }(\mathrm{mm})-17)}{3}\right) * 0.032\right)
\end{aligned}
$$

\section{TWR Model}

$$
\begin{aligned}
& 1.42+0.94 *\left(\frac{(\text { current }(\mathrm{A})-5)}{1.5}\right)-0.42 *\left(\frac{(\text { powder concentration }-3)}{3}\right)-0.09 *\left(\frac{(\text { tool diameter }(\mathrm{mm})-17)}{3}\right) \\
& +\left(\frac{(\text { current }(\mathrm{A})-5)}{1.5}\right) *\left(\left[\frac{(\text { powder concentration }-3)}{3}\right) *-0.085\right)+\left(\frac{(\text { current }(\mathrm{A})-5)}{1.5}\right) *\left(\left[\frac{(\text { tool diameter }(\mathrm{mm})-17)}{3}\right) * 0.13\right) \\
& +\left(\frac{(\text { powder concentration }-3)}{3}\right) *\left(\left[\frac{(\text { tool diameter }(\mathrm{mm})-17)}{3}\right) * 0.23\right)
\end{aligned}
$$

\section{Ra Model}

$$
\begin{aligned}
& 15.88+12.5563749999998 *\left(\frac{(\text { current }(\mathrm{A})-5)}{1.5}\right)+-2.2 *\left(\frac{(\text { powder concentration }-3)}{2}\right)-0.71 *\left(\frac{(\text { tool diameter }(\mathrm{mm})-17)}{3}\right) \\
& +\left(\frac{(\text { current }(\mathrm{A})-5)}{1.5}\right) *\left(\left[\frac{(\text { powder concentration }-3)}{3}\right) *-1.47\right)+\left(\frac{(\text { current }(\mathrm{A})-5)}{1.5}\right) *\left(\int\left(\frac{(\text { tool diameter }(\mathrm{mm})-17)}{3}\right) * 0.9\right) \\
& +\left(\frac{(\text { powder concentration }-3)}{3}\right) *\left(\left[\left(\frac{(\text { tool diameter }(\mathrm{mm})-17)}{3}\right) *-1.13\right)\right.
\end{aligned}
$$

\section{OPTIMIZATION}

The three models have been optimized using a desirability function method in JMP software. Figure 1 shows the desirability function for multi-objective optimization for three objectives: maximization of MRR, minimization of TWR, and minimization of surface roughness. The results show that an MRR of $0.046(\mathrm{~g} / \mathrm{min})$, TWR of $3.6(\mathrm{mg} / \mathrm{min})$ and $\mathrm{Ra}$ of $1.4(\mu \mathrm{m})$ can be achieved with $68 \%$ of desirability with current of $3.5(\mathrm{~A})$, powder concentration of $6(\mathrm{~g} / \mathrm{l})$ and tool diameter of $20(\mathrm{~mm})$. 


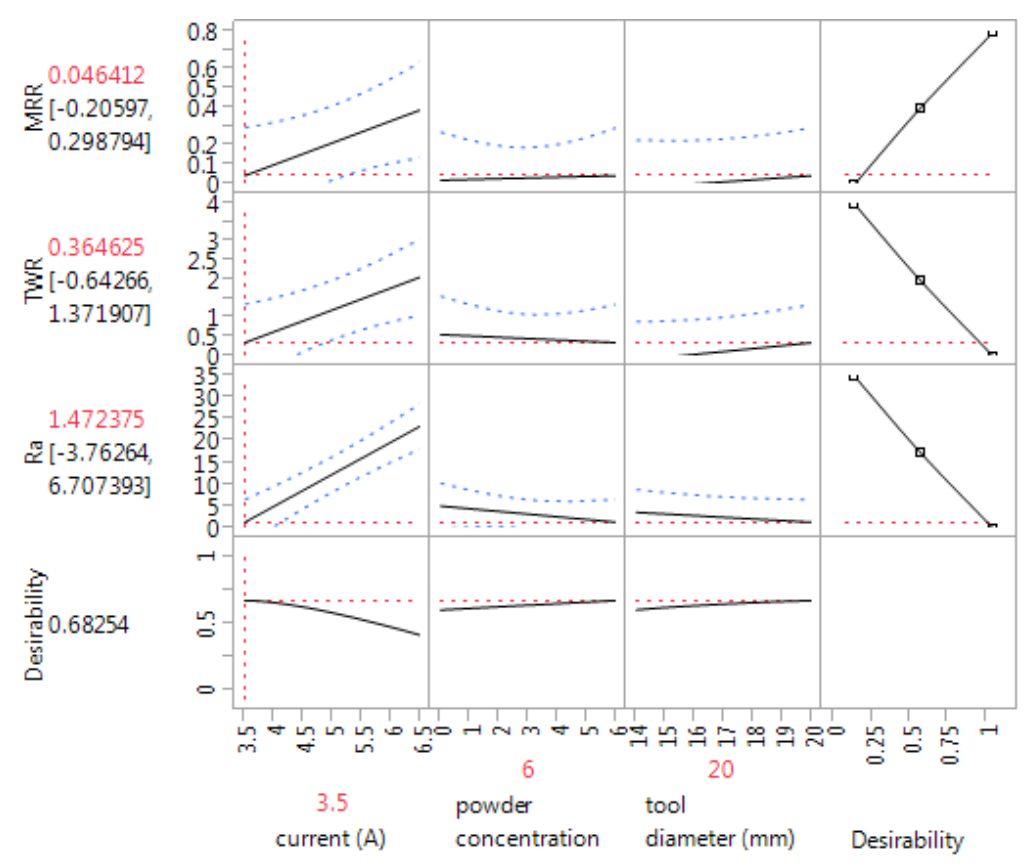

Fig. 1: Desirability function results.

\section{CONCLUDING REMARKS}

Nickel powder was suspended into the EDM dielectric fluid to enhance the process output. Three independent factors have been considered to measure the MRR, TWR, and surface roughness. The results show the following:

- Increasing the current had a negative effect on both the TWR and surface roughness. In contrast, the current increase had a positive effect on the MRR.

- Increasing the powder concentration positively affected the MRR while negatively affecting the TWR and Ra.

- Tool diameter had a negative effect on the MRR, while increasing the tool diameter reduced the TWR.

- The ratio of MRR to TWR was calculated and the results show that the current had limited effect on the ratio.

\section{ACKNOWLEDGEMENT}

We would like to show our gratitude to the Research Management Center, International Islamic University Malaysia for their support to conduct our research. We would like also to thank our colleagues in the Department of Manufacturing and Materials Engineering.

\section{REFERENCES}

[1] Sandeep K. (2013) Current research trends in electrical discharge machining: a review. Research journal of Engineering Sciences, 2(2):56-60.

[2] Webzell S. (2001) That First Step into EDM in Machinery. United Kingdom,UK: Findlay Publications Ltd.

[3] Livshits AL. (1960) Introduction in Electro-Erosion Machining of Metals. Department of Scientific \& Industrial Research, Butterworth \& Co., London. 
[4] Zhao WS, Meng QG, Wang ZL. (2002) The application of research on PMEDM in rough machining. Journal of Materials Processing Technology, 129:30-33.

[5] Kansal H, Singh S, Kumar P. (2003) State of the art concerning powder mixed EDM. In Proceedings of the International Conference on Emerging Technology (ICET-2003) KIIT, Bhubansewar, India.

[6] Sharma S, Kumar A, Beri N, Kumar D. (2010) Effect of aluminium powder addition in dielectric during electric discharge machining of hastelloy on machining performance using reverse polarity. International Journal of Advanced Engineering Technology, I(III):13-24.

[7] Abbas NM, Solomon DG, Bahari MF. (2007) A review on current research trends in electrical discharge machining (EDM). International Journal of machine tools and Manufacture, 47(7):1214-1228.

[8] Pecas P, Henriques E. (2003). Influence of silicon powder-mixed dielectric on conventional electrical discharge machining. International Journal of Machine Tools and Manufacture, 43(14):1465-1471.

[9] Jeswani ML. (1981) Effects of the addition of graphite powder to kerosene used as the dielectric fluid in electrical discharge machining. Wear. 70:133-139.

[10] Prihandana, G. S., Mahardika, M., Hamdi, M., Wong, Y. S., \& Mitsui, K. (2009). Effect of micro-powder suspension and ultrasonic vibration of dielectric fluid in micro-EDM processes-Taguchi approach. International Journal of Machine Tools and Manufacture, 49(12-13), 1035-1041.

[11] Kansal HK, Singh S, Kumar P. (2005) Parametric optimization of powder mixed electrical discharge machining by response surface methodology. Journal of Materials Processing Technology, 169(3):427-436.

[12] Yan BH, Tsai HC, Huang FY. (2005) The effect in EDM of a dielectric of a urea solution in water on modifying the surface of titanium. International Journal of Machine Tools and Manufacture, 45(2): 194-200.

[13] Ojha K, Garg RK, Singh KK. (2011) The effect of nickel micro powder suspended dielectric on EDM performance measures of EN-19 steel. Journal of Engineering and Applied Sciences, $6(1): 27-37$. 